\section{Why Branch Campuses May Be Unsustainable}

\section{Philip G. Altbach}

Philip G. Altbach is Monan University Professor and director of the Center for International Higher Education at Boston College.

$\mathrm{B}_{\mathrm{r}}^{\mathrm{r}}$ ranch campuses are sprouting around the world, like mushrooms after a heavy rain. According to the Observatory on Borderless Higher Education, the number of branch campuses have increased by 43 percent to a total of 162 between 2006 and 2009 (See Rosa Becker's article in this issue of IHE). Definitions are slippery; the Observatory's description will suffice:

"An international branch campus is an off-shore entity of a higher education institution operated by the institution or through a joint venture in which the institution is a partner (some countries require foreign providers to partner with a local organization) in the name of the foreign institution. Upon successful completion of the course program, which is fully undertaken at the unit abroad, students are awarded a degree from the foreign institution."

Many of the growing mushrooms may only hold a limited life span and a few might be poisonous. Let us be honest about branch campuses. With a few notable exceptions, they are not really campuses. They are, rather, small, specialized, and limited academic programs offered offshore to take advantage of a perceived market. Not surprisingly, the most popular programs offered are in business management and information technology - with fairly low setup costs and significant worldwide demand. Except where generous hosts-such as in the Arabian Gulf, Singapore, and a few other places-provide facilities and infrastructure, branch campuses become rather spartan places, resembling office complexes rather than academic institutions.

\section{The Future Crisis of the Professoriate}

Ensuring that the professors teaching at branch campuses come from the home university typifies perhaps the greatest problem of sustainability. It is actually difficult to lure home faculty to branch campuses for a long period. Thus, courses are often taught in intensive modules. Without faculty from home, does the branch in fact comprise part of the home institution? Often, branch campuses hire professors who lack an affiliation or experience at the home campus. If the sponsor is an American institution efforts are made to find, as instructors, Americans in the region of the branch or elsewhere and sometimes locals who have US experience. Similarly, administrators and other staff are frequently not from the sponsoring institution.

The ability to attract home campus professors to the branches has been undermined. Research-active senior faculty feel reluctant to leave their work, especially in the sciences. Junior faculty worry that overseas teaching will not serve their chances for promotion. Concerns about the education of children, employment of spouses, and other family issues also intervene. Even in cases where additional remuneration and other benefits are offered, it is frequently difficult to lure professors overseas. The problem is exacerbated over time. The relatively small number of home-campus faculty willing to relocate is restricted and quickly exhausted.

\section{Replicating the Home Campus}

Branches typically offer a limited curriculum-generally in fields that attract large enrollments, require limited infrastructure, and are relatively inexpensive to teach. Branch campuses seldom reflect the home university in terms of facilities, the breadth of curriculum, or the experience of studying at the sponsoring institution. As governments, accreditors, overseas partners, and students become more savvy about their educational goals, they may demand the "real thing" in the branches. An interesting case is the University of Liverpool's joint-

The most popular programs offered are in business management and information technology-with fairly low setup costs and significant worldwide demand.

venture campus with Xi'an Jiao Tong University in Suzhou, China. Mainly focused on teaching, Liverpool's Chinese partners have requested that the campus be research focused because Liverpool itself is a research-led university in the United Kingdom. It will be difficult for Liverpool to replicate this in China. With regard to the Johns Hopkins University's medical program in Singapore, the local authorities did not feel it was providing the promised goals, resulting in the cancellation of the program.

\section{Replicating the Students}

For a branch campus to provide an education equivalent to the form offered at the home university, the student body must largely match the one at home in terms of selectivity and quality. Especially for the more prestigious institutions-such as Cornell, Liverpool, Monash, and some others-this model will be difficult to sustain. For the many less-highly ranked institutions sponsoring branches, maintaining a branch campus will not be as problematic. It is questionable even now that most branches accept only students who would be qualified at home. These problems will likely become more serious given the increased competition for the top students in the host countries. 
In some cases, the pool of available students may become unpredictable as more branches are developed, and local institutions are inevitably improved. This particularly serious problem will likely infiltrate the Arabian Gulf region, where numerous branches have been established and the local and perhaps even the regional student population will have many other options over time. Some of the branches, established generally with funding from host governments or other agencies, are already facing enrollment problems, and many are operating under capacity.

\section{Changing Local Conditions}

The higher education environment has become fluid in many parts of the world. Demand for higher education expanded throughout the developing world, resulting in large numbers of students going overseas to study as well as a significant demand for branch campuses in countries with inadequate domestic provision or where the quality of local institutions is perceived as low. In the immediate future, expansion is anticipated to be strong due to broad demand for access to both mass and elite institutions. But the longer term is more difficult to predict. Many countries, such as China, are expanding local capacity at all levels, and branch campuses may soon be less attractive. India, which has not allowed much foreign involvement, may be opening its doors soon. At the same time, local capacity at the top is quite limited. India has announced plans for significant expansion of its selective institutions, including more Indian Institutes of Technology, which will for the first time be open to international students. In short, the future market for branch campuses is difficult to predict.

For a branch campus to provide an education equivalent to the form offered at the home university, the student body must largely match the one at home in terms of selectivity and quality.

\section{RISKS AND DANGERS}

Much is unclear about branch campuses. Universities establishing them have in general not considered the long-term implications. Establishing a real branch campus that provides an education the same as at the home institution is not an initially easy task, and it is much more difficult as time goes on. Sustainability should be a central concern when establishing a branch campus, but there is little evidence of such a concept. And the longer-term prospects in the countries where branches are being set up remain unclear. Branch campuses may be the "flavor of the month," but the pitfalls, with resulting damage to academic reputations, financial losses, and of course poor service to students, loom as significant prospects.

\section{International Branch Campuses: New Trends and Directions} ROSA BECKER

Rosa Becker is senior researcher at the Observatory on Borderless Higher Education. Address: Woburn House, 20-24 Tavistock Square, London WC1H ${ }_{1} H F$, UK. E-mail: r.becker@obhe.ac.uk. Web site: www.obhe.ac.uk. The full report, International Branch Campuses: Markets and Strategies, is available to Observatory members at http://www.obhe.ac.uk/documents/view_details?id=770.

S ince 2006 the number of international branch campuses $S$ in the world have increased by 43 percent, according to a new report published by the Observatory on Borderless Higher Education (OBHE). Branch-campus establishments have also taken some new directions.

\section{DeFinitions}

There is no universally agreed definition of an international branch campus, and apart from the Observatory's 2006 branch-campus report, no official and comprehensive list appears to include all existing branch campuses in the world or in specific regions around the globe. Both factors make it difficult to analyze and compare emerging trends across countries.

The term international branch campus is used here as an offshore entity of a higher education institution operated by the institution or through a joint venture in which the institution is a partner (some countries require foreign providers to partner with a local organization) in the name of the foreign institution. Upon successful completion of the course program, which is fully undertaken at the unit abroad, students are awarded a degree from the foreign institution.

As distinctions between branch campuses, satellite campuses, and study centers are blurred, subjective judgment is often required to conclude whether a certain operation exists. The traditional branch campus is characterized by academic and student facilities (such as a library, student accommodation, and recreational activities), research facilities, and a range of course offerings. This article, however, also refers to smallerscale operations that offer at least one full-degree program at their own independent offices (i.e., not located within a foreign university).

Certain establishments do not fit OBHE's definition of branch campuses. Not included are schools with more than one institution's courses and those with programs offered through a partner institution or only providing joint and double degrees; foreign campuses that only offer parts of a degree program; or study-abroad campuses for home students. Also excluded from this article are operations modeled on a foreign country's higher education system but without ties to a specific institution (such as the American University of Cairo); and foreign-backed universities, which have been established with- 